\title{
Anthrovision
}

Vaneasa Online Journal

Vol. 7.2 | 2019

Epistemic Disobedience

\section{Shared Video Work and Shared Writing}

Producing Knowledge in Solidarity

José Alfredo Jiménez Pérez and Axel Köhler

\section{OpenEdition}

Journals

Electronic version

URL: http://journals.openedition.org/anthrovision/5712

DOI: 10.4000/anthrovision. 5712

ISSN: 2198-6754

Publisher

VANEASA - Visual Anthropology Network of European Association of Social Anthropologists

Electronic reference

José Alfredo Jiménez Pérez and Axel Köhler, "Shared Video Work and Shared Writing ", Anthrovision

[Online], Vol. 7.2 | 2019, Online since 10 November 2020, connection on 27 January 2021. URL: http:// journals.openedition.org/anthrovision/5712 ; DOl: https://doi.org/10.4000/anthrovision.5712

This text was automatically generated on 27 January 2021.

(c) Anthrovision 


\section{Shared Video Work and Shared Writing}

Producing Knowledge in Solidarity

José Alfredo Jiménez Pérez and Axel Köhler

\section{Participation and Shared Work}

1 In order to examine the meaning of shared video work and shared writing in its epistemic $^{1}$ dimension, we first distinguish between participation and shared work, intentionally avoiding the term "collaboration". ${ }^{2}$ Most projects require the participation of several people at different levels. However, by "shared work", we refer to working together proactively in a collective project, which includes the decisionmaking processes. It is desirable to share equally the responsibilities and the workload, and to distribute tasks according to the participants' skills, although in practice this is not easily achieved. Although we may share goals, we may disagree on the strategies to accomplish them. Also, everybody is different in terms of character, skills, rhythm and energies. Without going deeper into the many challenges of collective enterprises, we want to outline the following conditions of shared work: someone initiates a collective project and others join; together they define a plan and agree on how to realise it. Each participant assumes the responsibilities s/he can handle-some more than others- and in the process of carrying out the project, key decisions are shared or modified according to feedback from the participants.

2 We consider it important to differentiate between proactively shared work and other forms of participation of a more reactive nature. For instance, shared work in a video project goes beyond the participation of subjects in their representation. For us, it means more than simply giving permission to record an activity, answering questions to an interviewer, commenting on the editing style or suggesting changes in the narrative structure of the product. 
3 In order to ground our discussion of shared work in a video project, and given that our reflections here are exclusively written ones, we shall start with the critical issue of how we actually wrote this chapter together.

\section{Our Co-authorship}

4 We grew up in life-worlds of very different experiences and knowledges. Nonetheless, we have coincided for over ten years now in media-related issues and have worked together on the basis of a shared interest in visualising non-hegemonic ways of knowing the world. This task entails experimenting with new methodologies and exploring other forms of representation. Our proposal is to discuss ways of shared work that we have discovered and experienced independently, but also together and in dialogue.

Of course, we are not the first to engage in shared or collaborative research and knowledge production. The first North American research collaborations between anthropologists of European descent and members of First Nations that resulted in coauthored ethnographies started in the late nineteenth century. They include the substantial work of Franz Boas and George Hunt on Kwakiutl culture and society, and that of Alice Fletcher and Francis La Flesche on "The Omaha Tribe" published in 1911 (Lassiter 2005b: 27-29, 35-36). ${ }^{3}$ Among our contemporary colleagues in Latin America we should mention at least the work of Bastos and Cumes (2007), as well as of Leyva, Burguete, and Speed (2008).

6 As George Marcus (2001: 521) has pointed out, the anthropological crisis of representation in the 1980s was partly due to the idea of collaboration and the de facto but unrecognised co-authorship of ethnography. Indeed, Lassiter calls "collaborative ethnographies" those works that explicitly recognise co-authorship with "consultants" (formerly "informants"). However, not all co-authors actually contribute to writing up. Lassiter (2005a: 96) indicates, for example, a model, which engages the consultant as narrator and the ethnographer as compiler and translator. His conclusion is: "Cowriting of texts with consultants is not always possible, but to my mind collaborative reading and editing (especially that which pushes toward cointerpretation) is what ultimately makes an ethnography collaborative" (Lassiter 2005a: 96). ${ }^{4}$ Based on her own and others' collaborative ethnographic work, Rappaport (2008: 1) has emphatically endorsed its value and quality, including the co-production of theory: "A series of collaborative projects with indigenous and African American communities have demonstrated that collaboration is not only a moral choice for progressive ethnographers but a choice that makes for good ethnography."

7 In our case, we started with a shared idea for a paper, each writing the part we considered essential for a shared text. Then we discussed and enriched our drafts, and realised that it was important not to obviate the dialogical process that inspired our writing together. So we decided that our personal voices, experiences, and knowledges should be distinguishable in the text. We did not want to simply turn a blind eye to what makes us different, but rather render transparent the fact that we articulate our ideas from distinct loci of enunciation.

Behind the action of co-writing and co-authoring are diverse scenarios of text and knowledge production. In most cases, co-authors tend to dissimulate these differences. 
A common strategy of voice is an undifferentiated "we," and a presentation of the text as a single narrative, neat and homogeneous. The effect of such merged or veiled coauthorship is an undifferentiated locus of enunciation. ${ }^{5}$ In our opinion, the personal and biographical particulars (gender, age, education, social class and status, ethnicity, professional experience) are what informs our voices and gives body to them. These particulars also legitimise, or limit, our capacity and power to represent. Therefore, it seems strange to ignore them, particularly in a text co-authored by an Indigenous American and a European.

In what follows, readers will find passages that represent the experiences and thoughts of one of us, and others where we take on a shared reflexive position, expressed in the first person plural. In our plural voice we present a shared view on practical and theoretical knowledge that derives from the Civil Society Organisation 'The Bees of Acteal' (The Bees) and social movements, but likewise from academic debate and the social sciences. The distinct epistemic origins of the arguments in the activist or the academic world are reflected in different styles of discourse and writing, which we have not attempted to homogenise, as that would betray the very different meanings that knowledge and knowledge-practices have in these contexts. As Aparicio and Blaser (2008: 86) argue, knowledge in a social movement or communitarian context is "relational, emergent and contextual", which is radically different from an academic context where knowledge is meant to be "an accurate representation of reality, better achieved as the observer is more detached".

10 Notwithstanding the distinct epistemic traditions, we come from, our aim is to reach a co-interpretation through critical feedback on each other's practical and theoretical knowledges. We focus on José's experience of communication processes within his organisation. His voice in the first person singular -or plural, when he expresses the collective experiences or knowledge of his organisation- is therefore prominent. It is worth pointing out though, that it has been honed and refined in our process of dialogue, debate and shared editing. For the translation of José's voice into English, Axel has tried to render it faithfully in style and delivery. We have already worked in this way for a co-authored book (Köhler et al. 2010), where each of the ten authors wrote his or her own chapter based on dialogues with a "creative partner" (see Leyva et al. 2010). Here we are taking this creative partnership a step further into shared authorship. The idea is to achieve what we might call a situated and reflexive coauthorship. Our co-authorship entails co-theorisation, that is, the "collective production of conceptual vehicles that draw upon both a body of anthropological theory and upon concepts developed by our interlocutors" (Rappaport 2008: 4-5).

\section{Who Are We?}

José Alfredo Jiménez Pérez: I am an indigenous Mexican citizen from the Tsotsilspeaking community of Yibeljoj in the municipality of Ch'enalvo' in the Highlands of Chiapas, where I was born in 1974. I am an active member of a social organisation, The Bees of Acteal, and have been working in community media for more than a decade. I am committed to my organisation and its cause out of a deep conviction. Like all other members of The Bees, I do my work as a service (cargo) to the organisation and the community without any remuneration. For me, this is a question of conscience, and there is no bigger satisfaction than fighting for justice and peace! 
12 Axel Köhler: I was born in 1956 in West Berlin, and trained as a social anthropologist at the Free University, Berlin, and later at the University of Manchester. For the last twenty years I have been living in San Cristóbal de Las Casas, where I work as a researcher-cum-lecturer at the Chiapas University of Sciences and Arts.

13 José: For family reasons, my school education finished at the primary level, but I restarted secondary education years later in a school for adults. Thus a lot of my knowledge and skills are self-taught outside an institutional setting. That is how I became proficient in reading and writing both my mother tongue and Spanish. I acquired my professional skills as a video-maker in workshops and learning by doing, always based on the needs of my organisation and informed by our Tsotsil Maya worldview. ${ }^{6}$

14 Axel: I acquired my professional skills at university and in the practice of anthropological research and teaching, within the epistemological canons of academia. But I also learned in practical fieldwork contexts with people from other cultures and forms of social and economic relations.

\section{Where Our Ethics and Knowledges Meet}

15 José shares a collective ethic with the members of his organisation, which is rooted in Tsotsil Maya traditional knowledge and transmitted by the elders of the community. This collective ethic also emphasises a culture of peace and the precepts of liberation theology. Axel's sense of right and wrong goes back to a Protestant upbringing and has been sharpened in critical academic and activist debates.

With regard to our respective social conscience and political practices, José has grown up with the thought and action of contemporary social movements, principally those that assert indigenous rights, autonomy and self-determination in cultural, educational and territorial matters, including the use of land and natural resources. He draws his fundamental inspiration from Tsotsil Maya cosmology and its indications as to how human beings relate to Mother Earth and other sentient beings -animals and plants- in harmonic coexistence.

17 Axel: My social conscience and political practice derive from a Western worldview and its critical traditions, particularly those that question instrumental reason and the idea of history as progress and civilisation. Historically, the evolutionary idea of a universal civilising process has spurred a European perception of superiority based on racial criteria and supposedly different biological structures. The current idea of economic progress through globalised capitalism reflects a still prevailing paradigm of the inevitable human domination of nature. Contemporary social and ecological movements and their calls for strengthening political participation and civic responsibility have also influenced my everyday practices.

\section{Education and the Decolonial Shift}

José: My dream is to offer our children a genuine education that is designed and developed by and for the community, and that strengthens our Tsotsil Maya roots, culture and identity. My idea is an education nourished and sustained by the knowledge and understanding that we have inherited from our ancestors. Hence it has 
to be constructed from the bottom up and not imposed from the top down. Unfortunately, the Mexican State provides public education that is not intended to endorse our culture and outlook, or to respect our rights. Quite the opposite in fact!

Creating a distinct educational model does not mean discarding useful knowledge that other societies and cultures have generated. But for us, education means first and foremost letting our children learn how to respect and value human rights, and how to use the natural resources provided by Mother Earth wisely and without harming anything or anybody. One way of contributing to a distinct, autonomous education is by encouraging community communication and the production of video and television programmes that counter the culture of violence and the supreme values of money and consumerism that the mass media, especially commercial television, are constantly transmitting.

Axel: One of my concerns is how to instigate a "decolonial shift" (Mignolo 2007) in academic practice and to be congruent with critical theory in everyday practices. Among the elements of a decolonial shift is a wider recognition of knowledges produced outside the academy, for instance, in other, non-European and non-colonial languages, and by non-written modes of representation. I deem video production to be a viable option in this direction.

\section{Building More Bridges}

21 In the preceding paragraphs we gave an outline of our social background, cultural roots and professional paths. ${ }^{7}$ They are the warp and weft onto which we began to weave the different threads of our thoughts and practices. The ideas we present here are borne of shared work, reflection and awareness building, and in that sense, they contribute to a co-production of knowledge that is "relational, emergent and contextual" (cf. Aparicio and Blaser 2008: 86). Although we have grown up in distinct life-worlds with different mother tongues, practices and skills, values, ideas, and feelings, we believe that these life-worlds are not incompatible and that it is crucial to build more bridges, both practical and theoretical, in order to improve our mutual understandings and create more empathy and solidarity. We found an opportunity to do that in the Chiapas Network of Artists, Community Communicators, and Anthropologist (Red de Artistas, Comunicadores Comunitarios y Antropolog@s en Chiapas, RACCACH) that we initiated together with eight other video-makers, painters, musicians, and anthropologists. Notwithstanding personal differences in terms of gender, age, ethnicity, social status and specific projects, this network has allowed the confluence of creative energies and critical collective reflection. As a group, RACCACH decided to realise a campaign among indigenous youngsters, aimed at encouraging them to participate in an emerging social, cultural and political movement and to engage more in community communications and artwork.

Having set out the conditions for our situated and reflexive co-authorship, we discuss shared work in video production as another possibility for co-producing knowledge in solidarity that is quite distinct from writing. In part, the goal is to reinforce our sharing practices with critical self-reflection, which has always characterised the collective spirit of the RACCACH network. Six of the ten members have shared work in this video production, bringing to it their many skills and knowledges. From the start, all six respected the original project of José and the communications department of The Bees, 
and each and every one made a contribution to the project. Along with others, all six shared in important decision-making processes at various stages of the project. Before we address the issue of shared video production, we shall introduce José's organisation and the social and political context in which the tragic subject matter of the video unfolded.

\section{The Bees and the Acteal Massacre}

In 1992, The Bees was founded as a social organisation in the municipality of Ch'enalvo' in The Highlands region of Chiapas. Its goal has always been the peaceful assertion of the rights of First Nations with a focus on the issues of land, natural resources and the defence of ancestral territories. ${ }^{8}$ In 1997, 45 members of The Bees, mostly women and children, were massacred in the community of Acteal by government-sponsored paramilitaries who had been trained by the state police and the federal army. ${ }^{9}$ The massacre was part of the counterinsurgency campaign the Mexican state had waged in order to deal with the consequences of the Zapatista uprising. ${ }^{10}$

Since 1997, The Bees have been campaigning through nonviolent action to denounce the massacre of Acteal as a state crime, ${ }^{11}$ to demand a thorough inquiry and to bring all those involved to justice. The wider aim is to bring an end to the prevailing conditions of impunity in Chiapas and Mexico. A number of organisations and groups from Mexico and around the world have joined the campaign, among them Human Rights Centres, the Popular Assembly of the Peoples of Oaxaca (APPO), and the People's Front for the Defence of the Earth (from Atenco near Mexico City). A significant part of our proposition focuses on the collective construction of "A distinct form of justice" (Otra justicia).

25 A major obstacle to achieving this justice arose in 2006, when the "Committee of Families and Friends for the Innocent Prisoners of the Acteal Case", with support from the Economic Research and Teaching Centre (Centro de Investigaciones y Docencia Económicas, CIDE), the magazine Nexos, the historian Héctor Aguilar Camín, Manuel Ansaldo and several evangelical pastors in Mexico initiated a campaign to free the imprisoned paramilitaries. On the eve of the Acteal Massacre's tenth anniversary, Aguilar Camín (2007) published a three-part article that attempted to rewrite the history of the event. It was based almost exclusively on the testimonies of some of the confessed assassins. In support of the campaign, CIDE also commissioned a video (Tapia and Abis Martínez 2007). The declared aim was to obtain an injunction before the Nation's Supreme Court, pleading for the release of those accused of the massacre on the grounds of having been "unjustly" imprisoned. For The Bees, the purpose behind the requested release of the prisoners was to prevent an investigation into those behind the massacre. In 2009, the Supreme Court decided to release several perpetrators of the massacre, despite the statements and the evidence supplied by witnesses and surviving family members who identified them as participants in the massacre. Twenty prisoners were released in 2009, and nine more in 2010. Although several of them had pleaded guilty, they were freed with the argument that there had been irregularities in the proceedings. It was therefore deemed "unconstitutional" to keep them prisoners. This means that from 1997 to 2010 the Mexican judicial system had not been capable of leading an investigation and bringing to justice the perpetrators or the intellectual authors of the massacre. With the release of these 
prisoners, the Supreme Court indirectly acknowledged that the system had not been able to accomplish its mandate.

\section{The Communications Department of The Bees}

In 2001, The Bees created a communications department in order to broadcast their demands and news to a wider audience. With its support, the organisation:

a) regularly issues press releases every 22 of the month and publishes them via email and its blog (http://acteal.blogspot.com);

b) participates in university, community and alternative radio programs, as well as in some commercial radio stations in Mexico;

c) has experimented with print media and has produced an internal newspaper; The Bees' demands for justice and the evidence for state-sponsored counterinsurgency and its strategy of low intensity warfare have also been published in national newspapers such as La Jornada and El Universal, and in the international press such as Lateinamerika Nachrichten, Neues Deutschland and other European newspapers;

d) has organised photo exhibitions in Acteal, San Cristóbal de Las Casas and Mexico City;

e) has received coverage on national and international television;

f) commemorates the massacre on the $22^{\text {nd }}$ of each month in Acteal, in a mass celebrated by the parish priest of Ch'enalvo', and honours the anniversary of the massacre together with the bishop and other church authorities on the $22^{\text {nd }}$ of December each year.

\section{Video as a Technology of Knowledge}

33 José: In 2003, the communications department of The Bees produced six editions of an internal newspaper. Outsiders, in solidarity with the organisation, commended the effort and praised the work, but members of the communities and the organisation never commented on the usefulness of the newspaper. We thus realised in the communications department that this newspaper was not serving its intended purpose, because we had not taken into account the low literacy rate in our communities. But since I am passionate about community media and convinced of its worth, I began to think hard on how to implement new communication processes in our communities, and reached the conclusion that my vocation was to become a video-maker. When we make videos ourselves, they may not be as professional as Mestizo ${ }^{12}$ productions, but they are certainly more original as they are closer to the people they represent. Members of a First Nation who make documentaries about their own people are better equipped for the task than outsiders, because they know their people's lifestyle and culture, their ways of doing, thinking and saying things and, above all, they can produce them in their own language.

Our videos express the feelings of our organisations, our knowledges and our truths. They represent the voices of our peoples' organised struggle and the social movements we participate in. In our Acteal video, people forcefully express that they consider the massacre to be a state crime, because it occurred in the context of the state's 
counterinsurgency campaigns. Nobody would be allowed to say that in state-controlled media, and few would be interested in doing so in commercial media. That is why we have to grow our own media.

I believe that our videos are making a valuable contribution to our culture and language, and represent our vision in a comprehensible way. Our videos also demonstrate that documentaries about our people and on issues important for us can be done in our languages, not only in Spanish or English. My idea for video making is precisely that our people become protagonists in this process and can see themselves on the screen; that is the meaning of our peoples appropriating the medium. When we organise screenings in our communities, people are very happy to see themselves and other First Nations on the screen.

I should also comment on the dual purpose of our videos. In the first instance, they are intended for internal communication among our people and organisations, and in second place, for external communication, i.e. for national and international civil society, so that its members can get information about what is happening in our communities. In the mass media we do not figure as political or historical agents of our country, so we have to assert our agency and make ourselves heard through our own media, where everyone has a voice and can take part. For that reason, we are appropriating video as a means of communication for us and by us.

Video reinforces our existing oral and visual traditions in its epistemic and aesthetic dimensions. Both the stories that our elders transmit and the embroidery that our women produce are an inspiration for our video productions. Oral tradition finds a more lively and authentic representation in a video recording when compared to a book. And the process of recording and editing the voice and image of our people in a video production is similar to the process of weaving the threads that produce the colourful fabric of our culture and history. Dreams are a third element of epistemic and aesthetic inspiration for us. They are a source of wisdom and allow us to see and hear what will happen in the future. They predict our calling as a healer, foretell our responsibility for a community cargo, and alert us to whether we are right or wrong. Video allows us to present our knowledge when we are awake, express our demands and denounce the ordeals we have to endure, as well as pointing to ways to heal as a society. In short, video is a means to communicate our understanding of the world in a contemporary medium. It is a new technology of knowledge that is, at present, much more effective for our people than writing.

\section{The Role of a Community Communicator}

José: I perceive my video making as a contribution to the struggle of my organisation. I offer an idea and a script, my camera and editing skills, and put my creativity and know-how to work. Our people in the communities contribute with what they know, giving life, colour and meaning to the videos. In Tsotsil we call that yak'bel xch'ulel, "giving life or soul" to something. As a video-maker, I consider myself to be a spokesperson for our organisation, but I am not doing my work as an individual. I always do it with the permission of the organisation's board and with the support of other members. When we made Acteal. Ten Years of Impunity. How Many More ${ }^{13}$, I first talked to the survivors of the massacre to find out whether they were willing to speak 
in front of the camera about their experiences. They agreed, and in the video they express in their own words our collective understanding and feelings.

Previously, I used to take credit for the videos I produced for the organisation. In the case of Acteal I did so in order to satisfy a requirement of the scholarship that I received for the project. The scholarship program only supported individuals, not organisations or groups. Yet, in The Bees we try to let go of the individualistic mentality that surrounds us and are in a continuous process of reflecting on our shared practices. We have to be consistent with what we say and practice, and since we work as a collective, we now credit our video productions to the organisation. So now the credits read: "made by the communications department of The Bees" and "produced by The Bees of Acteal".

\section{Video as a Media Strategy}

José: In my opinion, video has proven to be the most effective medium for communication in our campaign against impunity, because it goes beyond what written information can achieve. The audience can see and listen to the survivors of the massacre on the screen. Nobody is speaking for them. I would call that "first level" representation by a member of the organisation with the approval of its board and in tune with our politics of non-violence. I think such "first level" representation convinces the audience of our cause and vision. In screenings in Mexico, North America, and Europe, I have experienced personally the audience's empathy and their interest in finding out about the political reasons for the massacre and our fight against impunity. The testimonies of the survivors leave a deep impression on the viewers, and many have committed themselves to support our campaign, for instance, by publicising it, distributing the video or organising solidarity marches. In my experience, the video makes solidarity grow.

41 More than other media, video is also helping us to keep our collective memory alive. Several Mestizo and foreign directors have produced documentaries on the massacre and its causes, mainly based on testimonies of the survivors. ${ }^{14}$ In our own video, the survivors have also wanted to participate, but they express themselves in Tsotsil and speak from the heart and with more confidence. It is thus very important that we appropriate video for our purposes, since it allows us to convey the very word and image of our people who strongly remain immersed in an oral-visual culture.

We have also understood that video is an effective means for participating in the public sphere, that is, to let us be seen and heard. This is of utmost significance. How else can we defy hegemonic versions of our history as First Peoples? How can we make our voices heard and challenge from below what has been published about the massacre by the government-backed mass media?

\section{Shared Work and Epistemic Solidarity}

43 To give an idea of the shared work with other organisations that we counted on for the video, we shall mention their most important inputs. All of these contributions were made in a spirit of solidarity to support our campaign and to allow us to "write" in 
video our own history of the massacre. None of this work was financially rewarded; it was shared on the margins of capitalist logic and personal gain.

1) The Tseltal video-maker Mariano Estrada from The Ants-Committee for the Defence of Indigenous Liberation (Xi'nich-Comité de Defensa de la Liberación Indígena) put José's name forward for a Re: New Media scholarship ${ }^{15}$.

2) The anthropologist Xochitl Leyva from the Indigenous Video-Makers Project of the Southern Border (Proyecto Videoastas Indígenas de la Frontera Sur, PVIFS), helped to develop the project and the application for the scholarship.

3) The Friar Bartolomé de Las Casas Human Rights Centre (Centro de Derechos Humanos Fray Bartolomé de Las Casas, A.C.), the organisation's legal representative for the case of the Acteal massacre, provided access to archival materials and interviews with their lawyers.

47 4) The Boca de Polen Network of Communicators offered technical support, office space and infrastructure, and several of its members participated in the production. Jaime Schlittler was involved as assistant director, Chankin Ortega, Edgar Chávez, and Vladimir Contreras served as production assistants and helped with script-writing, camera work, editing and English subtitling.

5) The musicians Damián Martínez and Rie Watanabe of the bats'i rock group Sak Tzevul composed the music for the video.

6) Axel Köhler (PVIFS) provided the final English subtitling and helped with the screening and the distribution of the video both in communities and for an outside audience, for example, in university seminars, solidarity groups and film festivals.

This list is not exhaustive, but it shows how other indigenous and non-indigenous collectives and organisations engaged in every stage of the production and distribution of the video. What we want to emphasise is the solidarity with which they shared in the work, supporting José as the community communicator responsible for the project. They voluntarily contributed to a documentary produced by The Bees from the organisation's point of view. This does not mean that they could not make suggestions regarding the project. On the contrary, they took initiatives and shared important decision-making processes, but they were faithful to the original idea of the project for which José and the communications department of The Bees assumed the final responsibility.

51 These volunteers shared in the video production with a spirit and attitude that was very different to the times when Mestizos used to come with their own projects, telling members of the organisation what to do and how to participate. Now, The Bees define their own projects, assign those responsible for carrying them out, and decide on partnerships with outsiders on the basis of their commitment to a shared struggle for justice and peace. The efforts of these partners are meant to strengthen the cause and a self-determined appropriation of media, respecting the goals of the organisation and recognising its leadership in the process.

We thus propose to understand this shared work as epistemic solidarity, since it contributes specifically to rendering more visible existing alternatives to hegemonic knowledge and practice, and recognising them as viable. We take solidarity to be the guiding principle of knowledge, and the epistemic dimension of solidarity to be the basis for other forms of solidarity. Such solidarity is particularly significant in the case of communities and organisations that struggle for autonomy and ask little or nothing 
from the state. The definition of solidarity by Santos is crucial here: it is a form of knowledge in which "knowing is recognising the other as a subject of knowledge" (2005: 106). ${ }^{16}$

In their analysis of the unusual flow of knowledge from rural margins to metropolitan centres ("the lettered city"), and from social movements to academia, Aparicio and Blaser (2008: 60-61) remind us of Foucault's notion of an "insurrection of subjugated knowledges," as they speak of a current shift in knowledge-practices that is "contaminating" the dominant regime of power/knowledge. These subjugated knowledges are usually not represented in the mass media and therefore require the construction of alternative or independent media that frequently operate on the margins of capitalist logic. These alternative knowledge-practices, that resist globalising capitalism and its associated model of democracy as promoted by the Western centres of power, are also proposing other forms of education and administering justice. Their visibility and the recognition of their viability as alternatives to hegemonic knowledge-practices should be one of the pillars of democratic pluralism.

To close this section, we return to the distinction between reactive participation and proactively shared work that we outlined earlier. In the Acteal video as in many other indigenous media productions, the participatory process is the reverse of that cultivated by most ethnographic filmmakers. In ethnographic film, the participation of those being represented has often been sought in order to improve their representation, to make it more "authentic," and to raise the level of ethnographic "truth". However, ethnographic filmmakers do not necessarily give up on the ethnographic method or the possibility of an "objective" representation of other cultures produced from the outside. The participation of the subjects in their representation does not essentially transform the ethnographic gaze and the conditions of its production, although it can undoubtedly help to achieve greater verisimilitude. We certainly do not want to dismiss attempts to achieve more horizontal relationships in participatory ethnographic film but we do consider it worth pointing out the conceptual limits of ethnographic film, be it participatory or not. Filmmakers working within this genre generally maintain overall control of their projects; they obtain the budget and other resources required for the production, develop the narrative structure, and define the objectives and the target audience. It comes as no surprise then that the representation and knowledge they produce is from their perspective and with their aims, not those of the people they represent.

\section{Conclusions 1: Epistemic Solidarity in an Ecology of Knowledge}

Axel: With our reflections on shared work in writing and video production, our intention is to contribute to the struggles of First Peoples, in particular, the decolonisation of knowledge and the campaign of The Bees against impunity and for justice and peace. We also wish to encourage the appropriation of new technologies of knowledge and the growth of self-determined community media in solidarity.

In academic terms we want to strengthen the construction of an "ecology of knowledge" (Santos, 2005 and 2010) that seeks to integrate traditional knowledges with those produced by activists and academics. The idea of an ecology of knowledge is 
based on the recognition of the plurality of heterogeneous knowledge and the proposal that knowledge is really inter-knowledge (Santos 2010: 32). We have focused on the contribution that shared writing and video production can make to this ecology of knowledge through epistemic solidarity. We also sought to demonstrate that both shared writing and shared video production are complementary strategies of practicing epistemic solidarity.

What photographic images mean and can do in cognitive terms has been discussed from different perspectives. Among anthropologists, the debate included the pros and cons of images versus writing. Proponents of the written word have stressed that photography and cinema are not suitable to represent abstract thought and theory. This argument is not without foundation, but certainly no one would dispute that cinema or video can represent abstract thought and theory to the extent that its protagonists verbally express it. Unless one doubts the capacity for abstract thinking and theory building in humans with non-literate cultures, audiovisual media are a suitable means to represent it. Another point is "academic arrogance" (Fals Borda 2007: 21), the assumption that scientific knowledge -overwhelmingly produced in writing and in specialised academic language- is superior and more valuable than knowledge produced by other social actors. Academic arrogance is an integral part of what a group of Latin American intellectuals has called the "coloniality of knowledge" (e.g., Quijano, 2000; Mignolo 2002, 2007): the subordination of orality to literacy, of the languages and knowledges of colonised peoples to colonial languages and Eurocentric knowledge, of common sense to scientific reasoning. This theoretical framework for understanding the modern world as being founded on the coloniality of power, ${ }^{17}$ knowledge and being, puts into a global systemic perspective everyday experiences of racism and exclusion in the economic, political and social spheres. The task of decolonising knowledge is clearly part of the decolonisation of economics and politics that social movements are working towards, vindicating knowledges and practices otherwise.

\section{Conclusions 2: Communal Forms of Knowledges}

There was only immobility and silence in the darkness, in the night. Only the creator, the Maker, Tepeu, Gucumatz, the Forefathers, were in the water surrounded with light. They were hidden under green and blue feathers, and were therefore called Gucumatz. By nature they were great sages and great thinkers. In this manner the sky existed and also the Heart of Heaven, which is the name of God and thus He is called.

Then came the word. Tepeu and Gucumatz came together in the darkness, in the night, and Tepeu and Gucumatz talked together. They talked then, discussing and deliberating; they agreed, they united their words and their thoughts. (Popol Vuh, Anonymous 1954: 38)

José: The Bees, like many other social organisations, are proposing alternatives to the current world order. Our ways of being, thinking and doing are communal and collective. We are resisting a capitalist system that teaches us nothing but competition, where everybody only thinks of him or herself and does not care about others. Where there is no "us" but only "self," there is merely individualism.

Our collective and communal ways of thinking and doing things originate in the Maya universe and our Tsotsil Maya cosmology. The book of the Popol Vuh tells us that the 
"Creators and Makers," that is, the Maya Gods, came together to discuss and reach agreements on how the world was going to be:

And the Forefathers, the Creators and Makers, who were called Tepeu and Gucumatz said: "The time of dawn has come, let the work be finished, and let those who are to nourish and sustain us appear, the noble sons, the civilized vassals; let man appear, humanity, on the face of the earth." Thus they spoke.

They assembled, came together and held council in the darkness and in the night; then they sought and discussed, and here they reflected and thought. In this way their decisions came dearly to light and they found and discovered what must enter into the flesh of man. (Anonymous 1954: 121)

\section{BIBLIOGRAPHY}

\section{Books and articles}

Aguilar Camín, Héctor. 2007. Regreso a Acteal. Nexos (Mexico). October, November and December issues. http://www.nexos.com.mx (accessed June 2, 2018).

Anonymous. 1954. Popol Vuh. “The Book of the People.” Translated into English by Delia Goetz and Sylvanus Griswold Morley from Adrián Recino's translation from Quiché into Spanish. Los Angeles: Plantin Press.

Aparicio, Juan Ricardo and Mario Blaser. 2008. The 'Lettered City' and the Insurrection of Subjugated Knowledges in Latin America. Anthropological Quarterly 81(1): 59-94.

Arquilla, John and David Ronfeldt. 1998. The Zapatista Social Netwar in Mexico. RAND on-line publication. https://www.rand.org/pubs/monograph_reports/MR994.html (accessed September 3, 2020).

Arquilla, John and David Ronfeldt. 2000. Swarming and The Future of Conflict. Santa Monica, California: RAND Corporation \& National Defense Research Institute.

Bastos, Santiago and Aura Cumes, eds. 2007. Mayanización y vida cotidiana. La ideología multicultural en la sociedad guatemalteca. Vols. I, II y III. Guatemala: FLACSO, CIRMA and Cholsamaj.

Fals Borda, Orlando. 2007. La Investigación-Acción en convergencias disciplinarias. LASA Forum XXXVIII (4): 17-22.

Foucault, Michel. 2002 [1970]. The Order of Things. An Archaeology of the Human Sciences. London and New York: Routledge.

Haraway, Donna. 1988. Situated Knowledges: The Science Question in Feminism and the Privilege of Partial Perspective. Feminist Studies 14(3): 575-599.

Jiménez Pérez, José Alfredo. 2010. Sbonel jbijiltik. Dibujando nuestras sabidurías. In Sjalel kibeltik. Sts'isjel ja kechtiki'. Tejiendo nuestras raíces. Axel Köhler, et al. Pp. 308-315. Mexico: CESMECAUNICACH, CIESAS, UNAM, IWGIA, Orê, Xenix Filmdistribution, PVIFS, RACCACH, CDLI-Xi'nich, Sociedad Civil Las Abejas, Sak Tzevul, OMIECH, Oxlajunti' \& MirArte.

Köhler, Axel, Xochitl Leyva Solano, Xuno López Intzín, Damián Guadalupe Martínez Martínez, Rie Watanabe, Juan Chawuk, José Alfredo Jiménez Pérez, Floriano Enrique Hernández Cruz, Mariano 
Estrada Aguilar and Pedro Agripino Icó Bautista. 2010. Sjalel kibeltik. Sts'isjel ja kechtiki'. Tejiendo nuestras raíces. Mexico: CESMECA-UNICACH, CIESAS, UNAM, IWGIA, Orê, Xenix Filmdistribution, PVIFS, RACCACH, CDLI-Xi'nich, Sociedad Civil Las Abejas, Sak Tzevul, OMIECH, Oxlajunti' \& MirArte. http://jkopkutik.org/ (accessed September 3, 2020).

Köhler, Axel. 2010. Tocando Tierra. In Sjalel kibeltik. Sts'isjel ja kechtiki'. Tejiendo nuestras raíces. Axel Köhler et al. Pp. 343-352. Mexico: CESMECA-UNICACH, CIESAS, UNAM, IWGIA, Orê, Xenix Filmdistribution, PVIFS, RACCACH, CDLI-Xi'nich, Sociedad Civil Las Abejas, Sak Tzevul, OMIECH, Oxlajunti' \& MirArte.

Lassiter, Luke Eric. 2005a. Collaborative Ethnography and Public Anthropology. Current Anthropology 46(1): 83-106.

Lassiter, Luke Eric. 2005b. The Chicago Guide to Collaborative Ethnography. Chicago: University of Chicago Press.

Leyva Solano, Xochitl, Araceli Burguete and Shannon Speed, eds. 2008. Gobernar (en) la diversidad: experiencias indígenas desde América Latina. Hacia la investigación de co-labor. Mexico: CIESAS, FLACSO-Ecuador and FLACSO-Guatemala.

Leyva Solano, Xochitl and Shannon Speed. 2008. Hacia la investigación descolonizada: nuestra experiencia de co-labor. In Gobernar (en) la diversidad: experiencias indígenas desde América Latina. Hacia la investigación de co-labor. Xochitl Leyva, Araceli Burguete and Shannon Speed, eds. Pp. 65-107. Mexico: CIESAS, FLACSO-Ecuador and FLACSO-Guatemala.

Leyva Solano, Xochitl, Axel Köhler, Xuno López Intzín, Damián Guadalupe Martínez Martínez, Rie Watanabe, Juan Chawuk, José Alfredo Jiménez Pérez, Floriano Enrique Hernández Cruz, Mariano Estrada Aguilar and Pedro Agripino Icó Bautista. 2010. Introducción. In Sjalel kibeltik. Sts’isjel ja kechtiki'. Tejiendo nuestras raíces. Axel Köhler et al. Pp. 255-272. Mexico: CESMECA-UNICACH, CIESAS, UNAM, IWGIA, Orê, Xenix Filmdistribution, PVIFS, RACCACH, CDLI-Xi'nich, Sociedad Civil Las Abejas, Sak Tzevul, OMIECH, Oxlajunti' \& MirArte.

Marcus, George E. 2001. From Rapport under Erasure to Theaters of Complicit Reflexivity. Qualitative Inquiry 7: 519-528.

Merriam-Webster. 2003. Collegiate Dictionary. USA: Merriam-Webster, Inc.

Mignolo, Walter D. 2002. The Geopolitics of Knowledge and the Colonial Difference. The South Atlantic Quarterly 101(1): 57-96.

Mignolo, Walter D. 2007. Delinking: The rhetoric of Modernity, the Logic of Coloniality and the Grammar of de-Coloniality. Cultural Studies 21 (2-3): 449-514.

Peacock, James L. 2008. Reflections on Collaboration, Ethnographic and Applied. Collaborative Anthropologies 1: 163-174.

Quijano, Aníbal. 2000. Coloniality of Power, Eurocentrism, and Latin America. Nepantla: Views From the South 1(3): 533-580.

Rappaport, Joanne. 2008. Beyond Participant Observation. Collaborative Ethnography as Theoretical Innovation. Collaborative Anthropologies 1: 1-31.

Santos, Boaventura de Sousa. 2005. Sobre el postmodernismo de oposición. In El milenio huérfano. Ensayos para una nueva cultura política. Pp. 97-113. Madrid: Trotta.

Santos, Boaventura de Sousa. 2010. Para descolonizar el occidente. Más allá del pensamiento abismal. Buenos Aires: Consejo Latinoamericano de Ciencias Sociales - CLACSO and Prometeo Libros. 
Sierra, Jorge Luis. 2009. El apoyo del Ejército a los paramilitares. Revista Contralínea, September 13. https://www.contralinea.com.mx/archivo-revista/2009/09/13/el-apoyo-del-ejercito-a-losparamilitares/ (accessed September 3, 2020).

\section{Films}

Higgins, Nick. dir. 2008. A Massacre Foretold. Lansdowne Productions, 58 minutes.

Jiménez Pérez, José Alfredo, dir. 2008. Acteal: 10 años de impunidad ¿y cuántos más? Sociedad Civil Las Abejas. 44 minutes. http://acteal.blogspot.com. https://vimeo.com/11795328 (English subtitles) (accessed June 3, 2018).

Lacourse, Danièle and Yvan Patry, dirs. 2000. Sueño de Alonso. Alter-Ciné, First Run/Icarus Films, 71 minutes. https://www.youtube.com/watch?v=ULr4TC17lOE (accessed June 6, 2018).

Mendoza, Carlos and Víctor Marina, dirs. 1998. Acteal: Estrategia de muerte. Canal 6 de Julio, 48 minutes. https://www.youtube.com/watch?v=06u-sTRzk28 (accessed June 8, 2018).

Rojas Corte, Maximino, dir. 2005. Luces en Acteal. RC Comunicaciones, 43 minutes.

Tapia, Héctor and Juan Abis Martínez, dirs. 2007. Acteal, crónicas de impunidad. Alternativa Ciudadana 21 \& Cuarenta Producciones (production). 85 minutes.

\section{Websites}

Las abejas de Acteal. Sitio web de la Sociedad Civil Las Abejas. http://acteal.blogspot.com (accessed September 3, 2010).

Enlace Zapatista. http://enlacezapatista.ezln.org.mx (accessed September 3, 2010).

\section{NOTES}

1. We understand episteme to refer to a particular configuration of knowledge that characterises a society and a specific time, and that determines what counts as "knowledge" at that time: "In any given culture and at any given moment, there is always only one episteme that defines the conditions of possibility of all knowledge, whether expressed in a theory or silently invested in a practice" (Foucault 2002: 183).

2. Particularly, we want to avoid any connotation of collaboration as in "cooperate with or willingly assist an enemy of one's country and esp. an occupying force" (Merriam-Webster's Collegiate Dictionary 2003: 243). The negative connotations of such "collaboration" are significant in the context of a yet unresolved social and military conflict in Chiapas. For a discussion of collaboration -actual, sought or accused- between anthropologists and military or intelligence agencies, see Peacock (2008: 169-171). Publications by the anthropologists Arquilla and Ronfeldt (1998; 2000) on "cyberwar", "social netwars" and militant social activism are evidence of this kind of collaboration concerning the Zapatista uprising in Chiapas.

3. Lassiter (2005b) has written a critical history of collaborative ethnography and also launched an important Journal dedicated to Collaborative Anthropologies.

4. Elsewhere he defines it as "an approach to ethnography that deliberately and explicitly emphasizes collaboration at every point in the ethnographic process, without veiling it -from project conceptualization, to fieldwork, and, especially, through the writing process" (Lassiter 2005b: 16).

5. The issue here is not the content of co-authored writing or the particular arguments put forward. We find it unfortunate, though, when the merging of plural voices into one is left uncommented, especially in contexts of power differentials. For a long time, Europeans and 
Mestizos have represented Indigenous "Others" and spoken for them, and not only in the public sphere, politics and academia. For that reason, it is important to make clear our historically and geographically distinct sites of enunciation, because they correspond to marked locations in a "geopolitics of knowledge" (see Mignolo 2002).

6. The Tsotsil Maya worldview is common among Tsotsil-speaking peoples of Chiapas. Our staple is the sacred plant of maize, which brought forth our original totil me'il ("fathers-mothers"). We consider the earth to be our mother. Our kavilto vinik (religious authorities) are people with the ability and wisdom to communicate with the ojov', the sacred guardians of mountains and springs.

7. More about our respective personal histories and perspectives on life can be found in Jiménez Pérez (2010) and Köhler (2010).

8. For more information concerning The Bees and their campaign, consult http:// acteal.blogspot.com.

9. See Sierra (2009) for an analysis of two declassified documents by U.S. military intelligence. One of the documents "refers to the presence of military intelligence officers who oversaw paramilitary groups in The Highlands region of Chiapas during the time of the Acteal killings. According to information from the U.S. military attaché, the Mexican Army assigned young elements, usually with the rank of first and second captain, as well as sergeants, who speak indigenous languages of the region, the task of integrating intelligence cells, which collected information from communities and gave military training to armed groups in Chiapas" (https:// www.contralinea.com.mx/archivo-revista/2009/09/13/el-apoyo-del-ejercito-a-losparamilitares/) (all Spanish to English translations by the authors).

10. For information from the Zapatistas and the EZLN, consult http:// enlacezapatista.ezln.org.mx.

11. For concrete evidence supporting this claim, listen to the testimonies gathered in Jiménez Pérez (2008).

12. Mestizo is a term that refers to the non-indigenous population of Mexico. It was originally used for people of mixed European and Native American heritage or descent. Particularly in the 20th century, Mexican national identity was being built on the racial and cultural concept of mestizaje (miscegenation).

13. The original title in Spanish is Acteal: 10 años de impunidad ¿y cuántos más?

14. With one exception, all have taken a stand in support of our cause. See Mendoza and Marina (1998), Lacourse and Patry (2000), Rojas Corte (2005), Tapia and Abis Martínez (2007), and Higgins (2008).

15. Re: New Media was a North American organization that offered a program for Mexicans called "Scholarships for Audiovisual Arts" until 2007. They managed funds from the MacArthur and Rockefeller Foundations.

16. Donna Haraway, in her discussion of a "preferred positioning" in favour of a "view from below," i.e. of subjugated knowledges, characterised these as "partial, locatable, critical knowledges sustaining the possibility of webs of connections called solidarity in politics and shared conversations in epistemology" (1988: 584, italics added).

17. In Quijano's analysis (2000: 533-534, 541-542), one of the fundamental axes of colonial/ modern capitalism as a new model of global power is the social classification of populations based on the idea of 'race,' a supposedly different biological makeup that placed Europeans in a natural situation of superiority to other 'races' from America, Africa, and Asia. The identities produced on the basis of the idea of 'race,' became associated 'naturally' with the roles and places in a new structure of control of labour and its resources and products. As an integral part of the colonial capitalist domain, Europeans also achieved the control of subjectivity, culture and especially the production of knowledge. In the concomitant temporal perspective of world 
history constructed in Europe, colonised peoples were placed in the past and at the bottom of an evolutionary trajectory whose culmination was Europe.

\section{ABSTRACTS}

We examine the meaning of shared video work and shared writing in its epistemic dimension. Our reflections are based on our own experiences of working on the video Acteal. Ten years of impunity. How many more? produced by the communications department of the Civil Society Organisation 'The Bees of Acteal' in Chiapas, Mexico. We interpret the shared work in this production as an act of epistemic solidarity that contributes to the process of First Nations or First Peoples "sowing and growing" their own media at the margins of capitalist logic. We thus emphasise the appropriation of video as a technology of knowledge that can reinforce the oral and visual traditions of First Nations in their epistemic and aesthetic dimensions. We exemplify how The Bees have used video as a media strategy in their struggle for justice and peace and conclude that shared video work and shared writing are complementary strategies for an "ecology of knowledge" (Santos 2010) through epistemic solidarity.

Nous examinons la signification de la production vidéographique et de l'écriture partagées dans sa dimension épistémique. Nos réflexions sont fondées sur nos expériences de terrain à partir de la vidéo "Acteal. Dix ans d'impunité. Combien d'autres ? ". Ce film est produit par le département de communication de l'organisation de la société civile "Les Abeilles d'Acteal" au Chiapas, Mexique. Nous interprétons le travail collaboratif de cette production comme un acte de solidarité épistémique qui contribue au processus des Premières Nations ou des Premiers Peuples "semant et cultivant" leurs propres médias en marge de la logique capitaliste. Nous mettons donc l'accent sur l'appropriation de la vidéo comme technologie de la connaissance qui peut renforcer les traditions orales et visuelles des Premières Nations dans leurs dimensions épistémiques et esthétiques. Nous illustrons comment les Abeilles ont utilisé la vidéo comme stratégie médiatique dans leur lutte pour la justice et la paix et nous concluons que le travail vidéographique et l'écriture partagée sont des stratégies complémentaires pour une "écologie de la connaissance" (Santos 2010) à travers la solidarité épistémique.

Examinamos el significado del trabajo compartido en la producción de videos y de textos escritos. Nos basamos en experiencias propias en el video Acteal: 10 años de impunidad ¿y cuántos más? (Jiménez Pérez 2008) producido por el área de comunicación de la Organización Sociedad Civil Las Abejas de Acteal en Chiapas, México. Interpretamos la co-labor en esta producción como un acto de solidaridad epistémica que pretende contribuir, al margen de la lógica capitalista, al proceso de los pueblos originarios de sembrar sus propios medios de comunicación. Enfatizamos el uso que Las Abejas de Acteal le han dado al video como una estrategia mediática en su lucha por la justicia y la paz y ejemplificamos su apropiación como tecnología de conocimiento que fortalece las tradiciones orales y visuales en sus dimensiones epistémicas y estéticas. Concluimos que la co-labor videográfica y escrita responde a estrategias complementarias para una "ecología del saber" (Santos, 2010) a través de la solidaridad epistémica. 
INDEX

Palabras claves: video-producción compartida, co-autoría, co-labor, solidaridad epistémica, Masacre de Acteal, Chiapas, México.

Mots-clés: production vidéo partagée, coauteur, co-travail, solidarité épistémique, massacre d'Acteal, Chiapas, Mexique

Keywords: shared video production, co-authorship, epistemic solidarity, Acteal massacre, Chiapas, Mexico.

\section{AUTHORS}

JOSÉ ALFREDO JIMÉNEZ PÉREZ

Organización Sociedad Civil Las Abejas de Acteal, Ch'enalvo' (Chenalhó), Chiapas, Mexico jvaychil@gmail.com

\section{AXEL KÖHLER}

Universidad de Ciencias y Artes de Chiapas, Centro de Estudios Superiores de México y Centroamérica

axel.kohler@unicach.mx 